\section{LESSON 61}

Boxed ruled display with heading shorter than the longest column line

\section{Tabulation 20}

PAPER: A5 (210 x $148 \mathrm{~mm})$.

TARGET TIME: 10 minutes.
In Lesson 46 you learned how to display a tabulation when the heading was the longest line. Now the heading is the shortest line.

The technique is the same except that it is the heading which must be centred about the middle of the column.

Study this display. It is to be typed on a sheet of A5 paper (210 x $148 \mathrm{~mm})$.

\begin{tabular}{|l|l|}
\hline \multicolumn{1}{|c|}{ Apples } & \multicolumn{1}{|c|}{ Pears } \\
\hline $\begin{array}{l}\text { James Grieve } \\
\text { Worcester Pearmain } \\
\text { Sunset }\end{array}$ & $\begin{array}{l}\text { Conference } \\
\text { Comice } \\
\text { Pitmaston Duchess }\end{array}$ \\
\hline
\end{tabular}

Step 1 Calculate the left margin and tab points.

Step 2 Calculate the top and bottom margins on the sheet.

Step 3 Put in the underscore points and turn up two single-line spaces.

Step 4 Find the middle of the first column.

If you set the left margin and tab points on the vertical lines you must tap on the space bar:

Linespace Wo rc es te $r$ (and the space) Pe ar ma in spaceline

(If you set the left margin and tab points on the start of the columns you must tap on the space bar:

Wo rc es te r(and the space) Pe ar ma in)

Step 5 Backspace once for every two letters in the title. Backspace: Ap pl es Type Apples

Step 6 Centre the title over the second column. To do this find the middle of the column as indicated above and backspace Pe ar (s) Ignore the odd letter, s.

Step 7 Carriage return. Put in the underscore points and turn up two single-line spaces.

Step 8 Finish the display and rule up in ink or ball point pen.

Type this display on a sheet of A5 paper $(210 \times 148 \mathrm{~mm})$ and rule up.

\begin{tabular}{|l|l|}
\hline Marigold & \multicolumn{1}{|c|}{ Petunia } \\
\hline First Lady & $\begin{array}{l}\text { Appleblossom } \\
\text { Red Ensign } \\
\text { Orange Lady } \\
\text { Moonshot } \\
\text { Appollo }\end{array}$ \\
& $\begin{array}{l}\text { Sascade } \\
\text { Cascidge }\end{array}$ \\
\hline
\end{tabular}

